\title{
USLOVLJENO ČLANSTVO SRBIJE U EVROPSKOJ UNIJI VEĆ ZAMORENOJ OD PROŠIRENJA - KOLIKO JE DALEKO 2025. GODINA?*
}

\author{
Anila Jelesijević \\ Ambasada Švajcarske u Beogradu***
}

$u$ radu se analizira politiku proširenja Evropske unije u periodu od 2014. godine, kad je Republika Srbija otvorila pregovore o članstvu sa Unijom do 2018. godine kad se prvi put govori o 2025. godini kao mogućoj godini proširenja Evropske unije. Sa ciljem boljeg razumevanja politike proširenja, ovaj rad uzima u obzir i ostale važne događaje i dokumente pre pomenutog perioda. Autorka nastoji da dokaže da je politika proširenja EU u fazi zamora od proširenja koji se ispoljava kroz nejasnu kredibilnu politiku proširenja i perspektivu o neizvesnom članstvu. lako je EU pokazala da je željna da finansijski pomogne daljem razvoju zemalja ovog regiona njena politika o proširenju ne sledi takvu „finansijsku euforiju“. Autorka je mišljena da su krize kroz koje je EU prošla, političko uslovljavanje vezano za zemlje kandidate, zahtevi za ispunjavanje svih reformi pre članstva, samo izgovori EU koja nije spremna da prihvati zemlje Zapadnog Balkana. U slučaju Srbije, političko uslovljavanje koje implicitno zahteva priznanje nezavisnosti Kosova i suprotstavljanje Rusiji nije garancija da će ova zemlja postati član EU. Autorka zaključuje da 2025. godina bi mogla da bude godina proširenja ukoliko Evropska unija to zaista želi.

Ključne reči: Evropska unija, zemlje Zapadnog Balkana, zamor od proširenja, kredibilna politika proširenja, finansijska euforija, političko uslovljavanje, krize, Srbija, nezavisnost Kosova, 2025. godina

\section{Uvod}

Clan lanstvo u Evropskoj uniji svakako doprinosi razvoju određene zemlje. Prethodni talasi proširenja, a posebno oni koji su obuhvatili zemlje juga (Mediteran) i istoka Evrope doprineli su geopolitičkoj stabilnosti, kao i ekonomskom prosperitetu tih evropskih oblasti. ${ }^{1}$ I sam proces ka integraciji u EU ima svoje pozitivne efekte za zemlje kandidate

\footnotetext{
* Tekst je nastao kao deo istraživanja autorke za potrebe izrade njene doktorske disertacije.

** Asistent za informisanje.

*** Stavovi izneti u ovom radu predstavljaju lična shvatanja autorke a ne i institucije u kojoj je zaposlena.

${ }^{1}$ Duško Lopandić, Evropska unija i Srbija - novo vreme i novo okruženje, Štampa Grafolik, Beograd, 2017. str. 106-108.
} 
s obzirom da omogućava modernizaciju njihovog pravnog, ekonomskog i administrativnog sistema. Uostalom, EU pruža stabilan bezbednosni, politički i ekonomski okvir za položaj i razvoj manjih i srednjih zemalja (pa time i Srbije) koji je povoljniji od međunarodnih okolnosti u kojim vladaju klasični odnosi ravnoteže snaga i uticaja na koji male i slabe zemlje ne mogu mnogo uticati. ${ }^{2}$

Mogućnost apliciranja za članstvo (ali ne i članstvo) je regulisano članom $49^{3}$ Ugovora o funkcionisanju Unije: „Svaka evropska država koja poštuje vrednosti navedene u članu $2^{4}$ i koja se zalaže za njihovo promovisanje, može podneti zahtev za članstvo u Uniji...". Kad je u pitanju članstvo zemalja Zapadnog Balkana, njihova Evropska budućnost je najbolje istaknuta u tački 2, Solunske deklaracije iz juna 2003. godine: “...EU ponavlja svoju nedvosmislenu podršku evropskoj perspektivi zemalja zapadnog Balkana. Budućnost Balkana je unutar Evropske unije...". Sem preciziranja da napredak svake zemlje prema EU će zavisiti od njenih vlastitih zasluga u ispunjavanju Kopenhaških kriterijuma i uslova postavljenih Sporazumom o stabilizaciji i pridruživanju /SSP, ${ }^{6}$ za Srbiju se takođe govori i o podržavanju Rezolucije 1244 Saveta bezbednosti UN o Kosovu i politike UNMIK-a ", standardi pre statusa“. ${ }^{7}$ Od 2003. godine pa na dalje, kad je Zapadni Balkan ušao u fokus interesovanja Evropske unije, EU je pokazala da je željna da finansijski pomogne daljem razvoju zemalja ovog regiona ali njena politika o proširenju ne sledi takvu „finansijsku euforiju“. Unija je u martu 2014. godine uspostavila novi instrument podrške državama koje se nalaze u procesu pridruživanja i pristupanja EU - Instrument za pretpristupnu pomoć II. ${ }^{8}$ Za period 2014-2020. godine određeno je ukupno 11,7 milijardi evra za zemlje Zapadnog Balkana, od čega okvirno 1,5 milijardi evra za Srbiju. ${ }^{9}$ Sem toga, od 2007. do 2017. godine, Evropska unija je bila glavni trgovinski partner država Za-

\footnotetext{
${ }^{2}$ Duško Lopandić, Evropska unija i Srbija - novo vreme i novo okruženje, Štampa Grafolik, Beograd, 2017., str. 120.

${ }^{3}$ Official Journal of the European Union, CONSOLIDATED VERSION OF THE TREATY ON THE FUNCTIONING OF THE EUROPEAN UNION, 26.10.2012. izvor: internet: https://eur-lex.europa.eu/legal-content/EN/TXT/PDF/?uri=OJ:C:2012:326:FULL\&from=EN ; (pristupljeno 17.06.2019)

${ }^{4}$ Član 2: Unija se zasniva na vrednostima poštovanja ljudskog dostojanstva, slobode, demokratije, jednakosti, vladavine prava i poštovanja ljudskih prava, uključujući prava pripadnika manjina. Ove vrednosti su zajedničke državama članicama u društvu u kojem prevladava pluralizam, nediskriminacija, tolerancija, pravda, solidarnost i jednakost između žena i muškaraca; dostupno na: Official Journal of the European Union, CONSOLIDATED VERSION OF THE TREATY ON THE FUNCTIONING OF THE EUROPEAN UNION, 26.10.2012. izvor: internet: https://eur-lex.europa.eu/legal-content/EN/TXT/PDF/?uri=OJ:C:2012:326:FULL\&from=EN; (pristupljeno 17.06.2019.)

${ }^{5}$ European Commission, 10229/03 (Presse 163), EU-Western Balkans Summit, Thessaloniki, 21 June 2003, izvor: internet: http://europa.eu/rapid/press-release_PRES-03-163_en.htm; (pristupljeno 17.06.2019.), tačka 2.

${ }^{6}$ European Commission, 10229/03 (Presse 163), EU-Western Balkans Summit, Thessaloniki, 21 June 2003, izvor: internet: http://europa.eu/rapid/press-release_PRES-03-163_en.htm ; (pristupljeno 17.06.2019.), tačka 4.

${ }^{7}$ Više o tome u: European Commission, $10229 / 03$ (Presse 163), EU-Western Balkans Summit, Thessaloniki, 21 June 2003, izvor: internet: http://europa.eu/rapid/press-release_PRES-03-163_en.htm; (pristupljeno 17.06.2019.), tačka 5.

${ }^{8}$ Republika Srbija, Ministarstvo za evropske integracije, Instrument za pretpristupnu pomoć 2014-2020, izvor: internet: http://www.mei.gov.rs/srl/fondovi/fondovi-evropske-unije/ipa-instrument-za-pretpristupnu-pomoc/instrument-zapretpristupnu-pomoc-2014-2020/ ; (pristupljeno 25.06.2019.)

${ }^{9}$ Republika Srbija, Ministarstvo za evropske integracije, Instrument za pretpristupnu pomoć 2014-2020, izvor: internet: http://www.mei.gov.rs/srl/fondovi/fondovi-evropske-unije/ipa-instrument-za-pretpristupnu-pomoc/instrument-zapretpristupnu-pomoc-2014-2020/ ; (pristupljeno 25.06.2019.)
} 
padnog Balkana sa skoro $72 \%$ trgovinske razmene tih zemalja. ${ }^{10} \mathrm{U}$ slučaju Srbije, za isti period, Unija je takođe i najveći investitor sa uloženih 11.515,33 milijardi evra ili $75 \%$ ukupnih investicija. ${ }^{11}$ lako Evropska unija ne isključuje prihvatanje zemalja Zapadnog Balkana kao članove „svoje porodice“, stiče se utisak da nije baš povoljno vreme za njeno proširenje i da se zapravo radi o dugogodišnjem zamoru od proširenja. Takva politika Unije prema proširenju se čak i percipira kao proces pristupanja bez članstva u kojem, države kandidati se suočavaju sa politikom uslovljavanja kroz jasno pisanih uslova (kriterijumi iz Kopenhagena, 1993. godine i Madrida, 1995. godine) i nepisanih uslova (ad hoc odluke u oblasti visoke politike, koje odražavaju geostrateške prioritete Evropske unije). ${ }^{12}$ Sa druge strane, postoji i mišljenje o „mamurluku od proširenja“ prema kojem, duboka kriza dugova nisu u potpunosti zaustavili proces proširenja, iako su ga značajno usporili. ${ }^{13}$ Ipak „mamurlički optimizam“ je očigledno vezan za sticanje statusa kandidata ${ }^{14}$ jer se ne radi o nekom novom članstvu.

U međuvremenu, prema shvatanju Evropske unije, „politika proširenja nastavlja da daje rezultate i reforme napreduju u većini zemalja, mada različitim tempom“. ${ }^{15}$ Unija takođe priznaje da se radi o dugoročnom procesu s obzirom na složenu prirodu potrebnih reformi tokom kojih strukturni nedostaci opstaju, naročito u ključnim oblastima vladavine prava i u ekonomiji. ${ }^{16}$ Evropska unija naglašava „dobrosusedske odnose i regionalnu saradnju Zapadnobalkanske šestorke (WB6) kao ključni delovi procesa proširenja i procesa stabilizacije i pridruživanja“ uz tvrdnju da „bilateralni sporovi ne smeju da sputavaju proces pristupanja." ${ }^{17}$

${ }^{10}$ Glavni trgovinski partneri zemalja Zapadanog Balkana od 2007 do 2017.godine: EU 28- 71.9\%; Kina 5.8\%; Rusija 4.7\%; Turska 4.2\%; SAD 2.0\%; dostupno na: European Comission, European Union Trade in goods with Western Balkans 6 2007-2017, izvor: internet: https://webgate.ec.europa.eu/isdb_results/factsheets/region/details_western-balkans6 en.pdf (pristupljeno 19.06.2019), str. 8.

${ }^{11} \mathrm{EU}=11.515,33$ milijardi evra ili $75 \%$; Rusija $=1.472,34$ milijardi evra ili 9\%; Švajcarska $=904.09$ miliona evra ili 6\%; UAE = 365,09 miliona ili 2\%; Kina $=288,15$ miliona evra ili $2 \%$; SAD = 254,81 ili 2\%; Hong Kong = 240,82 miliona evra ili $2 \%$; Crna Gora $=140,35$ miliona evra ili 1\%; Koreja $=91,34$ miliona evra ili 1\%; Bosna i Hercegovina $=84,7$ miliona evra ili $1 \%$; ostatak sveta $=363,83$ miliona evra ili $2 \%$, dostupno na: Delegation of the European Union to the Republic of Serbia, FDI to Serbia, izvor: internet: https://europa.rs/serbia-and-theeu/trade/fdi-in-serbia/?lang=en ; (pristupljeno 20.06.2019)

${ }^{12}$ Više o tome u: Slobodan Samardžić, Evropska unija: Sistem u krizi; sa studijom slučaja o odnosima Srbije i EU, Izdavačka knjižara Zorana Stojanovića, Sremski Karlovci-Novi Sad, 2016., str. 334-336; str. 676

${ }^{13}$ Više o tome u: Duško Lopandić, Evropska unija i Srbija - novo vreme i novo okruženje, Štampa Grafolik, Beograd, 2017. str. 106-108.

${ }^{14}$ Crna Gora vodi pregovore za članstvo od 2013. godine. Srbija je počela pregovore početkom 2014. godine. Albanija je zvanični kandidat za članstvo EU od 2014. godine. BiH podnela zahtev za članstvo Unije 2016. godine.

${ }^{15}$ Evropska komisija, Saopštenje o politici proširenja za 2016. godinu, izvor: internet: http://www.mei.gov.rs/upload/documents/eu_dokumenta/godisnji_izvestaji_ek_o_napretku/saopstenje_ek_o_p olitici_prosirenja_16.pdf; (pristupljeno 19.06.2019.) str. 2.

${ }^{16}$ Više o tome u: Evropska komisija, Saopštenje o politici proširenja za 2016. godinu, izvor: internet: http://www.mei.gov.rs/upload/documents/eu_dokumenta/godisnji_izvestaji_ek_o_napretku/saopstenje_ek_o_p olitici_prosirenja_16.pdf; (pristupljeno 19.06.2019.) str. 2.

${ }^{17}$ Evropska komisija, Saopštenje o politici proširenja za 2016. godinu, izvor: internet: http://www.mei.gov.rs/upload/documents/eu_dokumenta/godisnji_izvestaji_ek_o_napretku/saopstenje_ek_o_p olitici_prosirenja_16.pdf; (pristupljeno 19.06.2019.) str. 10. 
Zamor EU od proširenja ipak nije nova pojava, barem kad su zemlje Zapadnog Balkana u pitanju. Izjava tadašnjeg predsednika Srbije Borisa Tadića, 2008. godine da „se stiče utisak da Evropska unija u ovom trenutku nije spremna da prihvati zemlje Zapadnog Balkana tempom kojim bi svi voleli da imaju“, ${ }^{18}$ pokazuje da je čak i tada „optimizam o proširenju“ već bio prošlost. Od 2008. do 2018. godine samo je jedna zemlja pristupala Evropskoj uniji (radi se o Hrvatskoj koja je postala član 2013. godine). Između 2003. i 2018. godine nije bilo nijednog samita između šefova država i vlada država članica EU sa jedne strane i šest zemalja Zapadnog Balkana, ${ }^{19}$ dok je recimo visoka predstavnica za spoljnu politiku Evropske unije, Federika Mogerini (Federica Moghernini) prvi put posetila region 30 meseci nakon stupanja na funkciju. ${ }^{20}$

Uostalom „virus zamora“ je već bio prisutan i u Kopenhaškim kriterijumima za pristupanje u članstvo EU koje je postavio Evropski savet u junu 1993. godine. Tzv. kriterijum apsorpcije, odnosno sposobnost Unije da prihvata nove članove, se naziva i četvrtim kriterijumom Kopenhaških kriterijuma. ${ }^{21}$

Odugovlačenje EU u prihvatanju novih članova uglavnom se pripisuje stavu da je prijem 12 zemalja 2004. i 2007. i još jedne 2013. predstavljao preveliko opterećenje za EU koja nije u stanju da se nosi sa novim, dodatnim članicama. ${ }^{22}$ Sem toga, smatra se da su krize sa kojima se Unija suočava očigledno stavljale proširenje u drugi plan. Ipak, od njenog osnivanja, Evropska unija se pridržavala politike proširenja dok se istovremeno suočavala i sa različitim krizama. Kad su države Evrope počele da sarađuju u ekonomskom planu davne 1951. godine prvo formirajući Evropsku zajednicu za ugalj i čelik, a zatim, 1957. godine, Evropsku ekonomsku zajednicu i Evropsku zajednicu za atomsku energiju, broj članica je bio samo šest (Belgija, Nemačka, Francuska, Italija, Luksemburg i Holandija). Od tada pa do danas, Evropska unija broji 28 države članica koje su joj pristupile kroz nekoliko faza proširenja. ${ }^{23}$ Sa druge strane, u svim tim godina-

\footnotetext{
${ }^{18}$ Boris Tadić in an interview published in the daily Blic, 10 May 2009 u Jovan Teokarević, Western Balkan's EU integration: How to overcome the remaining obstacles, ivor: internet: https://drive.google.com/drive/mobile/folders/0B3p2GDMDp-_RbF96NFpUZ2NuRIU?usp=sharing_eip\&invite=CKTK2gL\&ts=5c0a2601; (pristupljeno 17.06.2019)

${ }^{19}$ Milena Lazarević, Away with the enlargement bogeyman, izvor: internet: https://cep.org.rs/wp-content/uploads/2018/07/Away-with-the-Enlargement-Bogeyman_CEP.pdf; (pristupljeno 19.06.2019), str. 1.

${ }^{20}$ Suzana Grubješić, Dometi Zapadnobalkanske Agende u: Dragan R. Simić, Dejan Milenković, Dragan Živojinović (ur.), Evropa za mene, Čigoja štampa, Beograd, 2018, str 685-687.

${ }^{21}$ Definisana su četiri kriterijuma za članstvo u EU: politički kriterijum: „stabilnost institucija koje garantuju demokratiju, vladavinu prava, ljudska prava i poštovanje i zaštitu manjina“; ekonomski kriterijum: postojanje funkcionalne tržišne ekonomije, kao i sposobnost države da se nosi sa pritiskom konkurencije i tržišnim snagama unutar Unije; EU acquis: sposobnost preuzimanja obaveza članstva, uključujući poštovanje ciljeva političke, ekonomske i monetarne unije; kapacitet apsorpcije: kapacitet Unije da prihvata nove članove, a da se pri tom zadrži evropskim integracijama; više o tome u: European Parliament, Copenhagen European Council - 21-22 June 1993, izvor: internet: http://www.europarl.europa.eu/enlargement/ec/cop_en.htm; (pristupljeno 18.06.2019)

${ }^{22}$ Suzana Grubješić, Dometi Zapadnobalkanske Agende u: Dragan R. Simić, Dejan Milenković, Dragan Živojinović (ur.), Evropa za mene, Čigoja štampa, Beograd, 2018., str. 685-687.

${ }^{23}$ 1973. godine: prvo proširenje - Danska, Irska i Velika Britanija; 1981. godine - Grčka; 1986. godine Španija i Portugal; 1995. godine: četvrto proširenje - Austrija, Finska i Švedska; 2004. godine: proširenje „veliki prasak" - najveće proširenje Unije do sad - Češka, Estonija, Kipar, Letonija, Litvanija, Mađarska, Malta, Poljska, Slovačka i Slovenija; 2007. godine: Bugarska i Rumunija; 2013. godine: Hrvatska.
} 
ma, razvoj EU je „prošao,, kroz nekoliko ozbiljnih kriza: od odbijanja francuskog parlamenta da prihvati Ugovor o osnivanju odbrambene zajednice (između Francuske, Nemačke i zemalja Beneluksa) tokom pedesetih godina prošlog veka, do suočavanja EU sa De Golovom upornom odbijanjem kandidature Velike Britanije u šezdesetim, kroz naftne krize i njihove posledice u sedamdesetim godinama pa do raspada i ratova u Jugoslaviji (1991-1999) tokom poslednje decenije prošlog veka. ${ }^{24}$ Zatim, prvu deceniju dvadeset prvog veka, je obeležio neuspeh predloga o „ustavnom ugovoru“, pa zatim institucionalne krize Unije nakon negativnih referenduma u Francuskoj i Holandiji (2004-2007), ekonomska kriza i kriza javnih dugova u nekim zemljama EU (2009. godine i kasnije), ${ }^{25}$ pa do migrantske krize koja je eskalirala 2015. godine.

Ako nije problem u krizama, onda se postavlja pitanje zašto EU oduglovlači sa članstvom zemalja Zapadnog Balkana? Bugarskoj je trebalo 12 godina da pristupi Evropskoj uniji (aplicirala je 1995. godine) dok je Hrvatskoj trebalo 10 godina (aplicirala 2003. godine). Srbija (aplicirala 2009. godine), Crna Gora (aplicirala 2008. godine), Severna Makedonija (aplicirala davne 2004. godine), Bosna i Hercegovina (aplicirala 2016. godine), još uvek čekaju da pristupe Evropskoj uniji. Slažemo se da zemlje Zapadnog Balkana nemaju isti svestrani razvoj poput 10 zemalja centralne i istočne Evrope koje su pristupile uniji 2004. godine, ali ipak smatramo da ulazak Bugarske i Hrvatske u EU koje su imale slične ekonomske performanse i probleme kao većina zemalja Zapadnog Balkana, je jedan od indikatora da Evropska unija još uvek ne želi da prihvati Zapadni Balkan. Primera radi, Bugarska u trenutku pristupanja EU je imala bruto domaći proizvod/BDP po glavi stanovnika 5.900 evra i stopu nezaposlenosti $18,1 \%{ }^{26}$ otprilike koliko je Crna Gora imala BDP i stopu nezaposlenosti 2015. godine (BDP po glavi stanovnika 5.800 evra; stopa nezaposlenost 17,5\%). ${ }^{27}$ Hrvatska, do trenutka pristupanja „vukla“ iste „izazove“ koje je imala godinama (nezavisnost pravosuđa, borba protiv organizovanog kriminala i korupcije, poštovanje i zaštite manjina, povratak izbeglica, suđenje za ratne zločine i puna saradnja sa Haškim tribunalom, dobri odnosi sa susedima i pitanje granica) $)^{28}$ koji su isti problemi sa kojim se suočavaju i zemlje Zapadnog Balkana.

\footnotetext{
${ }^{24}$ Više o tome u: Duško Lopandić, Evropska unija i Srbija - novo vreme i novo okruženje, Štampa Grafolik, Beograd, 2017, str. 48-49.

${ }^{25}$ Više o tome u: Duško Lopandić, Evropska unija i Srbija - novo vreme i novo okruženje, Štampa Grafolik, Beograd, 2017, str. 48-49.

${ }^{26}$ European Comission, 2003 Continuing enlargement - Strategy paper and Report of the European Commission on the progress towards accession by Bulgaria, Romania and Turkey.

https://www.esiweb.org/enlargement/wp-content/uploads/2009/02/ec-2003-strategy-paper.pdf (pristupljeno 26.06.2019) str. 42-43.

${ }^{27}$ European Comission, 2016 Communication on EU Enlargement Policy. https://ec.europa.eu/neighbourhood-enlargement/sites/near/files/20161109_strategy_paper_en.pdf (pristupljeno 26.06.2019), str. 31-32.

28 "...Croatia needs to meet outstanding closing benchmarks in the field of judiciary and fundamental rights, in particular building up the necessary track records as regards the independence and efficiency of the judiciary, the fight against corruption and organised crime, respect for and protection of minorities, including refugee return, war crimes trials and full cooperation with the ICTY including settling the issue of access for ICTY to documents ... Croatia is expected to continue to play an active role in regional cooperation in the Western Balkans..." dostupno na: European Comission, Enlargement Strategy and Main Challenges 2010-2011. https://ec.europa.eu/neighbourhoodenlargement/sites/near/files/pdf/key_documents/2010/package/strategy_paper_2010_en.pdf (pristupljeno 27.06 2019). str. 15.
} 
Objašnjenja o čekanju za pristupanje EU zbog toga što da Srbija mora da reši problem sa Kosovom, da Severna Makedonija je morala da reši spor oko njenog imena sa Grčkom (koji je rešen sredinom 2018. godine), da Bosna i Hercegovina mora da reši problem političke konsolidacije, svakako ne važe za Crnu Goru koja iako nema takvih problema mora da čeka barem do 2025. godine da bi eventualno pristupila Evropskoj uniji.

Ipak, cilj ovog rada nije da se bavi sudbinom svih zemalja Zapadnog Balkan na putu ka evropskoj integraciji nego da pokušava da ustanovi u čemu je problem nepristupanja Srbije u Evropskoj uniju. Period koji ćemo uzeti u razmatranju su odnosi Srbije i Evropske unije od 2014. do 2018. godine. Godina 2014. je važna za Srbiju zbog početka zvaničnog otvaranja pregovora o pristupanju Evropskoj uniji, kao prvi korak najvećem približavanju integraciji ka Uniji. Sem toga i početak Berlinskog procesa, avgusta iste godine, kao pokazatelj da Unija nije napustila zemlje Zapadnog Balkana, čine ovu godinu bitno za analiziranje. Naredne četiri godine će nam pokazati kakav je tempo kretanja Zapadnog Balkana (sa fokusom prema Srbiji) u procesu Evropskih integracija. Naše je mišljenje da Evropska unija još uvek nije željna da prihvati Srbiju kao ravnopravnog člana i da je njena politika uslovljavanja samo izgovor za odugovlačenje i neizvesnost ka članstvu u Uniji.

\section{Zamor od proširenja - opadajući optimizam politike proširenja Evropske unije}

Poslednjih godina, optimizam o proširenju se transformisao u optimizam o perspektivi proširenja koji u suštini znači neizvesna politika proširenja. Primera radi, jedina zajednička „stavka“ sve strategije Evropske unije o proširenju jeste o tome da se zovu strategije o proširenju. Postoji razlika između strategija o proširenju vezanih za pristupanje zemalja centralne i istočne Evrope i strategija o zemljama Zapadnog Balkana. Dok su strategije o proširenju centralne i istočne Evrope sa optimizmom i jasno vodile do pristupanja tih zemalja u EU, strategije o proširenju Zapadnog Balkan su dosta skeptične. Analizom tih strategije može da se primeti da se godinama optimizam o proširenju smanjuje. Optimizam Evropske unije o proširenju je praktično trajao tokom procesa takozvanog "big bang enlargement“ (proširenje „veliki prasak“) iz 2004. godine, kad su ovoj Uniji pristupili 10 novih članova. Od tada pa do 2018. godine, optimizam o proširenju više liči na nostalgiju o „big bang enlargement“ nego na želju za proširenje.

2014. godine, novo izabrana Evropska komisija, na čelu sa Žan Klod Junkerom (Jean Claude Juncker), izjavila je da tokom njenog petogodišnjeg mandata neće biti proširenja Evropske unije: „Evropska unija ce zamrznuti proširenje narednih pet godina.“29

Ni Globalna strategija EU iz 2016. godine, ne percipira politiku proširenja prema Zapadnom Balkanu kao glavni prioritet. Ovaj dokumenat koji je usvojen junu 2016. godine nakon referenduma o izlasku Velike Britanije iz EU ukazuje na „potrebu jake Evropske unije čije postojanje je dovedeno u pitanje. “30 lako ova strategija posvećuje posebno me-

\footnotetext{
${ }^{29}$ EU business, Juncker to halt enlargement as EU Commission head, izvor: internet: https://www.eubusiness.com/news-eu/politics-juncker.x29; (pristupljeno 19.06.2019)

${ }^{30}$ Više o tome u: European Union External Action, Shared Vision, Common Action: A Stronger Europe; A Global Strategy for the European Union's Foreign and Security Policy, June 2016, izvor: internet: http://eeas.europa.eu/archives/docs/top_stories/pdf/eugs_review_web.pdf (pristupljeno 19.06.2019), str. 3.
} 
sto politici proširenja, prvo kao prioritetu broj dva od ukupno pet prioriteta spoljne politike $\mathrm{EU}^{31}$, godina pristupanja EU ili eventualno predviđanje vremena proširenja su izostavljene. Zapadni Balkan se dalje pominje u okviru kredibilnog procesa pridruživanja.“32 Međutim, može da se kaže da je ovaj dokumenat više ohrabrujući za Zapadni Balkan nego recimo Bezbednosna strategija EU iz „zlatne godine“33 to jest 2003. lako u Bezbednosnoj strategiji Unije iz 2003. godine se naglašava da "Evropa nikad nije bila tako prosperitetna, tako bezbedna ni tako slobodna" ${ }^{34}$, region Zapadnog Balkana se očigledno tretira kao sveže sanirano mesto zahvaljujući pomoći SAD, Rusije, NATO i drugih međunarodnih partnera. ${ }^{35}$ Uostalom, ni proširenje koje se tada definisalo kao „sukcesivno proširenje" nije se odnosilo na Zapadni Balkan. ${ }^{36}$

Takođe, poslednja u Strategija o proširenju Evropske komisije iz 2018. godine je dokaz tzv. optimizma o perspektivi proširenja koji smo odredili kao neizvesnu politiku proširenja. Dokumenat počinje citiranjem izjave iz 2017. godine, predsednika Evropske komisije Žan Klod Junkera (Jean Claud Juncker), koji je ponovo je potvrdio evropsku budućnost zemalja Zapadnog Balkana. Međutim, već se da primetiti da optimizam o perspektivi proširenja se popunjava „izjavom o izostanku proširenja“ takođe izrečenoj tri godine ranije: "Ako želimo veću stabilnost u našem susedstvu, onda moramo održati verodostojnu perspektivu proširenja za Zapadni Balkan. Jasno je da neće biti proširenja tokom mandata ove komisije i ovog parlamenta". ${ }^{37}$ Ipak, u želji da pokaže spremnost Evropske unije ka daljem proširenju, pomenuta strategija predviđa da će Evropska komisija tokom 2018. godine izložiti niz inicijativa usmerenih na poboljšanje demokratskog, institucionalnog i političkog okvira za uniju 2025. godine, zasnovane na trenutnim ugovorima dok se naglašava da do tog datuma, EU bi mogla postati veća od 27 članova.

${ }^{31}$ pored sigurnosti Unije, integrisanog pristupa prema konfliktima, regionalne saradnje i globalnog upravljanja za 21. vek; više o tome u: European Union External Action, Shared Vision, Common Action: A Stronger Europe; A Global Strategy for the European Union's Foreign and Security Policy, June 2016, izvor: internet: http://eeas.europa.eu/archives/docs/top_stories/pdf/eugs_review_web.pdf (pristupljeno 19.06.2019)

${ }^{32}$ Više o tome u: European Union External Action, Shared Vision, Common Action: A Stronger Europe; A Global Strategy for the European Union's Foreign and Security Policy, June 2016, izvor: internet: http://eeas.europa.eu/archives/docs/top_stories/pdf/eugs_review_web.pdf (pristupljeno 19.06.2019), str. 9-10.; str. 24.

${ }^{33}$ Zadržavamo pravo da je tako nazovemo zbog pomenute optimističke deklaracije iz Soluna iz 2003. godine.

${ }^{34}$ European Council, A Secure Europe in a better world-European Security Strategy, Brussels, 12 December 2003, izvor: internet: http://eclan.eu/files/attachments/.1615/doc_10184_290_en.pdf; (pristupljeno 08.07.2019) str. 1.

${ }^{35}$ Više o tome u: European Council, A Secure Europe in a better world-European Security Strategy, Brussels, 12 December 2003, izvor: internet: http://eclan.eu/files/attachments/.1615/doc_10184_290_en.pdf; (pristupljeno 08.07.2019.) str. 1, 6, 8.

${ }^{36}$ European Council, A Secure Europe in a better world-European Security Strategy, Brussels, 12 December 2003, izvor: internet: http://eclan.eu/files/attachments/.1615/doc_10184_290_en.pdf; (pristupljeno 08.07.2019) str. 1.

${ }^{37}$ European Comission, A credible enlargement perspective for and enhanced EU engagement with the Western Balkans, izvor: internet: https://ec.europa.eu/commission/sites/beta-political/files/communicationcredible-enlargement-perspective-western-balkans_en.pdf (pristupljeno 18.06.2019.), str. 1.

${ }^{38}$ European Comission, A credible enlargement perspective for and enhanced EU engagement with the Western Balkans, izvor: internet: https://ec.europa.eu/commission/sites/beta-political/files/communicationcredible-enlargement-perspective-western-balkans_en.pdf (pristupljeno 18.06.2019.), str. 1-2. 
Optimizma o proširenju ili perspektivi proširenja recimo nema uopšte u izjavama francuskog predsednika Emanuela Makrona (Emmanuel Macron) koji je samo dva meseca posle te „obećavajuće strategije“ izjavio da Evropska unija ne treba da prihvati nijednu novu članicu sve dok se taj blok ne bude dublje integrisao i sproveo temeljne reforme. ${ }^{39}$ Najveći francuski državnik nije propustio priliku da to ponovi i tokom samita EU - Zapadnih zemalja u Sofiji, 17. maja 2018. godine, događaj koji je čak izbegavao da u rutinskoj deklaraciji uključi optimističke pojmove poput „integracije i proširenje“. ${ }^{40}$ U Sofijskoj deklaraciji sa tog samita, se govori samo o nedvosmislenoj podršci evropskoj perspektivi Zapadnog Balkana pozivajući se na Solunski samit iz 2003. godine, ${ }^{41}$ ali proširenje nije na vidiku. Da su rešavanja preostalih bilateralnih pitanja važna stavka EU a ne proširenje govore i ishodi Londonskog samita iz jula 2018. godine. Ni tamošnja zajednička deklaracija o regionalnoj saradnji i dobrosusedskim odnosima u okviru Berlinskog procesa ne govori o proširenju nego ističe obavezu zemalja potpisnica da će hitno rešiti preostala bilateralna pitanja i suzdržati se od zloupotrebe bilateralnih sporova koji bi blokirali put ka EU. ${ }^{42}$

Uostalom, zamor od proširenja je odavno postao „normalna“ pojava i među običnim građanima zemalja EU. Prema Eurobarometru iz 2007. godine, skoro svaki drugi Evropljanin je bio za dalje proširenje EU $(49 \%)$. ${ }^{43}$ Tada, u devet zemalja EU, procenat građana koji ne podržava dalje proširenje je bio ispod 50 posto; među njima Italija $(48 \%)$, Velika Britanija $(41 \%)$, Nemačka (34\%) i Francuska (32\%). ${ }^{44}$ Šest godina kasnije, $53 \%$ građana EU se protivilo proširenju i samo $37 \%$ ga je podržalo. ${ }^{45}$ Najveće protivljenje je tada obeleženo u Nemačkoj (75\%), Francuskoj (71\%), Finskoj (70\%) i Austriji (69 \%). ${ }^{46}$ Trend „zamora“ je nastavljen i 2017. godine sa podacima da samo 42\% Evropljana podržavaju ideju prihvatanja

\footnotetext{
${ }^{39}$ B92 NET, 2018. French president: EU must first reform, Balkans can wait. https://www.b92.net/eng/news/world.php?yyyy=2018\&mm=04\&dd=17\&nav_id=103956 (pristupljeno 26.06.2019)

${ }^{40}$ BALKAN INSIGHT, 2018. Enlargement Stays off Agenda at Sofia Summit. http://www.balkaninsight.com/en/article/sofia-summit-balkans-meet-europe-for-the-first-time-in-15-years-05-17-2018 pristupljeno 26.06.2019)

${ }^{41}$ Pozivajući se na samit u Solunu 2003. godine, EU ponovo potvrđuje svoju nedvosmislenu podršku evropskoj perspektivi Zapadnog Balkana...; dostupno na: EU-Western Balkans Summit, Sofijska deklaracija, 17. maj 2018. godine, izvor: internet: https://www.consilium.europa.eu/media/34805/sofia-declaration_bs.pdf (pristupljeno 19.06.2019), tačka 2, str. 1.

${ }^{42}$ Više o tome u: Western Balkans Summit, London 2018, Joint Declaration on Regional Cooperation and Good Neighbourly Relations in the Frame of the Berlin Process, izvor: internet:

https://assets.publishing.service.gov.uk/government/uploads/system/uploads/attachment_data/file/724294/180 710_WBS_Joint_Declarations.pdf (pristupljeno 18.06.2019.); Zoran Nechev, Ivan Nikolovski, Jelica Minić, Mariola Qesaraku and Adnan Ćerimagić, 2018 Western Balkans Summit: 3 key takeaways from London; izvor: internet: https://idscss.org.mk/wp-content/uploads/2018/12/Финална-верзија-на-бриф-веб-2.pdf ; (pristupljeno 18.06.2019.) str. 3-6.

${ }^{43}$ Eurobarometer 67, November 2007, Public opinion in the European Union, izvor: internet: http://ec.europa.eu/commfrontoffice/publicopinion/archives/eb/eb67/eb67_en.pdf ; str. 188-190.

${ }^{44} \mathrm{Ibid}$.

${ }^{45}$ European Comission, Standard Eurobarometer, No. 79, Spring 2013, izvor: internet: http://ec.europa.eu/commfrontoffice/publicopinion/archives/eb/eb79/eb79_anx_en.pdf, str. T84, (pristupljeno 18.06.2019)

${ }^{46}$ European Comission, Standard Eurobarometer, No. 79, Spring 2013, izvor: internet: http://ec.europa.eu/commfrontoffice/publicopinion/archives/eb/eb79/eb79_anx_en.pdf, str. T84, (pristupljeno 18.06.2019)
} 
novih članova. ${ }^{47} \mathrm{U}$ međuvremenu, u zemljama Zapadnog Balkana je obeležen zamor od čekanja. Kad je Srbija u pitanju, optimizam o članstvu iz novembra 2009. godine (73\% građana su bili za ulazak u EU) nije se zadržao do kraja 2018. godine (55\% građana su bili za ulazak u EU). ${ }^{48}$ Zamor od čekanja se najviše primećuje u periodu od decembra 2012. do decembra 2017. kad je podrška o članstvu u EU između 40\% i $50 \%$. ${ }^{49}$ Prema podacima iz 2018. godine, kao najveći uzrok usporavanja ulaska Srbije u EU građani su identifikovali politiku uslovljavanja i ucene koju EU primenjuje prema Srbiji.

lako članstvo u Evropskoj uniji ostaje spoljnopolitički prioritet Srbije, ${ }^{51}$ Unija je dala do znanja da treba da se reši kosovsko pitanje. Ipak, stav Unije po pitanju Kosova ostaje i dalje konfuzan. Za predsednika Srbije, Aleksandra Vučica, nema sumnje da je najveći problem evrointegracija Kosovo, a ne vladavina prava. ${ }^{52} \mathrm{U}$ roku od dva dana, u oktobru 2018. godine, Srbiji su preneta dva, u prvom pogledu, različita pristupa od strane Evropske unije i njenih država članica. Sudeći po izjavama poslanika nemačkog Bundestaga Petera Bajera (Peter Beyer), inače člana Hrišćanske-demokratske unije (CDU) Angele Merkel (Angela Merkel) i koordinatora transatlantske saradnje u nemačkom Bundestagu, Kosovo je faktički teritorijalno nezavisno i Srbija treba da prizna de jure "suverenu državu Republiku Kosovo", jer u suprotnom neće ući u Evropsku uniju. ${ }^{53}$ Međutim, za evropskog komesara za proširenje Johanesa Hana (Johannes Hahn), rešenje kosovskog pitanja nije jedini preduslov na putu Srbije ka EU jer sprovođenje reformi u oblasti vladavine prava, osnovnih prava i dobrog upravljanja ostaje u srži procesa proširenja. ${ }^{54}$ Upitan o tome kakve su šanse Srbije da postane članica do 2025. godine, Han je objasnio da je predsednik Evropske komisije Junker u više navrata jasno stavio do znanja da nijedna nova država članica ne može da pristupi EU bez rešavanja otvorenih bilateralnih pitanja, ${ }^{55}$ što u suštini podrazumeva i rešavanje kosovskog pitanja.

\footnotetext{
${ }^{47}$ European Commission, Europeans views on the priorities of the European Union, Standard Eurobarometer 88, November 2017 u Milena Lazarević, Away with the enlargement bogeyman, izvor: internet: https://cep.org.rs/wp-content/uploads/2018/07/Away-with-the-Enlargement-Bogeyman_CEP.pdf; (pristupljeno 19.06.2019.), str. 4.

${ }^{48}$ Više o tome u: Republika Srbija, Ministarstvo za evropske integracije, Evropska orijentacija građana Srbije, Ispitivanje javnog mnjenja, decembar 2018.godine, izvor: internet:

http://www.mei.gov.rs/upload/documents/nacionalna_dokumenta/istrazivanja_javnog_mnjenja/javno_menjnje_ decembar_18.pdf (pristupljeno 18.06.2019), str. 3-5.

${ }^{49} \mathrm{lbid}$.

${ }^{50}$ lbid.

${ }^{51}$ RTS, Aleksandar Vučic: "Članstvo u EU spoljnopolitički prioritet Srbije", http://www.rts.rs/page/stories/sr/story/9/politika/3304233/clanstvo-u-eu-spoljnopoliticki-prioritet-srbije.html; (pristupljeno 25.06.2019)

${ }^{52}$ Danas novine, Vučić: Najveći problem evrointegracija je Kosovo, ne vladavina prava, izvor: internet: https://www.danas.rs/politika/vucic-najveci-problem-evrointegracija-je-kosovo-ne-vladavina-prava/; (pristupljeno 20.09.2019)

${ }^{53}$ Blic novine, HLADAN TUŠ BERLINA Bajer Bez priznanja Kosova Srbija NEĆE UĆl U EU, izvor: internet: https://www.blic.rs/vesti/politika/hladan-tus-berlina-bajer-bez-priznanja-kosova-srbija-nece-uci-u-eu/hcj7ffg (pristupljeno 20.06.2019)

${ }^{54}$ B92, Mnogi misle da je jedini uslov za EU Kosovo. Nije., izvor: internet: https://www.b92.net/info/vesti/index.php?yyyy=2018\&mm=10\&dd=22\&nav_category=1262\&nav_id=1458960; (pristupljeno 20.06.2019)

55 lbid.
} 


\section{Srbija i njen proces integracije u Evropsku uniju - od Berlinskog procesa do Strategije o proširenju iz februara 2018. godine}

\section{Značaj Berlinskog procesa}

Berlinski proces je „lansiran“ samitom iz 28. avgusta 2014. godine u Berlinu između predsednika vlada, ministra spoljnih poslova i ministra ekonomije Albanije, Bosne i Hercegovine, Hrvatske, Kosova*, Makedonije, Crne Gore, Srbije, Slovenije, Austrije, Francuske, i predstavnika Evropske komisije, na inicijativu nemačke kancelarke Angele Merkel. ${ }^{56}$ Cilj ovog samita je bio postizanje zajedničkog dogovora o jačanju regionalne saradnje na Zapadnom Balkanu i utvrđivanje četvorogodišnjeg okvira (2014-2018. godina) za rešavanje preostalih otvorenih pitanja u regionu. ${ }^{57} \mathrm{U}$ finalnoj deklaraciji samita je navedeno da će „sve zemlje Zapadnog Balkana imati priliku da se pridruže Evropskoj uniji ako ispune uslove za pristupanje". ${ }^{58}$ Jasno je da Berlinski proces nije ubrzavanje procedure pristupanja EU jer ne obećava nikakvo proširenje nego samo konstatuje ono što je i drugim prilikama rečeno da će Zapadni Balkan postati deo EU jedino ako ispuni uslove za pristupanje. Tri godine kasnije, nemački ministar spoljnih poslova Zigmar Gabrijel (Sigmar Gabriel) objavio je novi plan za Zapadni Balkan agendu „Berlin plus“ kao dodatni podsticaj Berlinskom procesu. Gabrijel je agendu „Berlin plus“ koja predviđa dodatne napore ali i finansijska sredstva kako bi se ubrzalo napredovanje regiona ka EU predstavio 31 maja 2017. godine u Berlinu na konferenciji sa kolegama sa Zapadnog Balkana Instituta Aspen. ${ }^{59} \mathrm{~S}$ obzirom da ni takav paket nije pokazivao neke znake brzog proširenja, „Berlin plus“ nije oduševio Srbiju. Tadašnji vršilac dužnosti premijera i ministar spoljnih poslova Srbije Ivica Dačić je ocenio da nemački plan za Zapadni Balkan - Berlin plus, ne sme postati politički izgovor za EU da Srbiju "ostavi u svojoj čekaonici". 60

Ipak „de facto čekaonica za EU“ to jest Berlinski proces pa i „Berlin plus“ su očigledno deo politike neizvesnog proširenja Evropske unije. Sam taj proces stavlja u prvi red jačanje regionalne saradnje za rešavanje preostalih otvorenih pitanja u regionu dok će pristupanje EU nastaviti da zavisi od politike uslovljavanja.

\footnotetext{
${ }^{56}$ Ministarstvo spoljnih poslova Republike Srbije, Berlinski proces, izvor: internet:

http://www.mfa.gov.rs/sr/index.php/spoljna-politika/eu/regionalna-saradnja/2016-11-04-09-04-26?lang=lat; (pristupljeno 21.06.2019)

${ }^{57}$ lbid.

${ }^{58}$ Die Bundesregierung, Press release, Final Declaration by the Chair of the Conference on the Western Balkans, 28 August 2014,

izvor: internet: https://archiv.bundesregierung.de/archiv-de/meta/startseite/final-declaration-by-the-chair-ofthe-conference-on-the-western-balkans-754634 ; (pristupljeno 20.06.2019)

${ }^{59}$ INTERMAGAZIN.RS, Nemačka objavila plan za Balkan - „BERLIN PLUS“, izvor:internet: https://www.intermagazin.rs/nemacka-objavila-plan-za-balkan-berlin-plus/ ; (pristupljeno 27.06.2019)

${ }^{60}$ N1, Dačić: Zbog plana Berlin plus da ne ostanemo u čekaonici EU, izvor: internet: http://rs.n1info.com/Vesti/a274280/Dacic-o-planu-Berlin-plus.html (pristupljeno 27.06.2019)
} 


\section{Dokle je Srbija stigla sa pregovaranjem o članstvu sa EU- Politika Evropske unije prema Srbiji po modelu „štapa i šargarepe“}

Kad je u pitanju proces integracije Srbije u Evropsku uniju, mišljenja smo da Unija primjenjuje prema Srbiji politiku po modelu „štapa i šargarepe“. Takva politika se ispoljava kroz faze proširenja i u okviru Zajedničke spoljne i bezbednosne politike unije/ZSBP i sastoji se od višestrukog uslovljavanja čiji se prioriteti vremenom menjaju.

Za Srbiju, kredibilna politika proširenja EU je politika uslovljavanja prvenstveno rešavanjem kosovskog pitanja. Dokument iz prve međunarodne konferencije iz 2014. godine između Srbije i EU o otvaranju poglavlja za pristupanje Uniji naglašava da je kredibilna politika proširenja ključna za održavanje reformi i javna podrška proširenju u državama članicama. ${ }^{61}$ Kako je dalje navedeno, od Srbije se očekuje da će kontinuirano: a) sprovoditi u dobroj veri sve dogovore postignute u dijalogu sa Kosovom; b) u potpunosti poštovati principe inkluzivne regionalne saradnje; c) dijalogom i duhom kompromisa rešiti druga otvorena pitanja, na osnovu praktičnih i održivih rešenja i sarađivati u tehničkim i pravnim pitanjima vezanih za Kosovo; d) efektivno sarađivati sa EULEKS. ${ }^{62}$ Takođe je navedeno da će pitanje normalizacije odnosa između Srbije i Kosova biti obrađeno u poglavlju 35: "ostala pitanja" kao posebna stavka, koja treba da se reši tokom procesa pregovora o pristupanju. ${ }^{63}$ Važno je pomenuti i „klauzulu ravnoteže” odnosno paragraf 24 ovog dokumenta koji određuje otvaranje ili zatvaranje poglavlja na osnovu procene napretka u poglavljima 23 i 24 odnosno "pravosuđe i osnovna prava" i "pravda, sloboda i sigurnost". 64 Međutim, „klauzula ravnoteže“ se „uravnotežuje“ prema slučaju Kosovo. „Klauzula ravnoteže“ će se primenjivati mutatis mutandis u slučaju da napredak u normalizaciji odnosa sa Kosovom, koji se razmatra u poglavlju 35 , značajno zaostaje za napretkom u pregovorima u celini. ${ }^{65}$

Od prve Međuvladine konferencije 21. Januara 2014. godine do kraja 2018. godine, Srbija je otvorila 16 , a privremeno zatvorila 2 poglavlja. ${ }^{66}$ Treba imati u vidu da je dinamika otvaranja i zatvaranja poglavlja vezana sa gore pomenutom tzv. klauzulom o ravnoteži. Ako Srbija namerava da 2025. postane članica EU, sva poglavlja treba da se otvore i zatvore do kraja 2023., kako bi se tada potpisao Ugovor o pristupanju, čija ratifikacija u zemljama članicama traje 18-24 meseca. ${ }^{6}$

Ako je u ranijim godinama, to jest posle potpisivanja SSP akcenat više stavljen na puno saradnju sa Haškim tribunalom, poslednjih godina, rešenje statusa Kosova je najja-

\footnotetext{
${ }^{61}$ više o tome u: Council of the European Union, Conference of the accession to the European Union-Serbia-, Accession Document, Brussels, 9 January 2014, izvor: internet: http://register.consilium.europa.eu/doc/srv?l=EN\&t=PDF\&gc=true\&sc=false\&f=AD\%201\%202014\%20INIT (pristupljeno 21.06.2019.), str. 4 .

62 Ibid. str. 10-11.

${ }^{63}$ lbid.

${ }^{64}$ Ibid. str. 12.

${ }^{65} \mathrm{lbid}$.

${ }^{66}$ European Commission, Serbia 2019 Report, Brussels, 29.5.2019 SWD, izvor: internet: https://ec.europa.eu/neighbourhood-enlargement/sites/near/files/20190529-serbia-report.pdf; (pristupljeno 27.06.2019) str. 3.

${ }^{67}$ Suzana Grubješić, Dugi marš do Evropske unije u Dragan R. Simić, Dejan Milenković, Dragan Živojinović (ur.), Evropa za mene, Čigoja štampa, Beograd, 2018, str. 528.
} 
či imperativ. Primera radi, strategije o proširenju Evropske komisije do 2013. godine stavljaju u prvi red „nastavak pune saradnje sa Haškim tribunalom“ pa onda govore o „vidljivom i održivom poboljšanju odnosa sa Kosovom" ${ }^{\text {“68 }}$ Od 2014. godine pa nadalje, strategije o proširenju Evropske komisije naglašavaju potrebu nastavka dijaloga sa Prištinom, i usklađivanje spoljne i bezbednosne politike Srbije sa politikom Evropske unije. ${ }^{69} \mathrm{Ne}$ treba zaboraviti da Sporazum o stabilizaciji i pridruživanju (SSP) Srbije sa EU, koji je bio potpisan 2008. godine, tupio na snagu 1. septembra 2013. godine, nekoliko meseci posle potpisivanja u aprilu Sporazuma o principima normalizacije odnosa između Srbije i Kosova (tzv. Briselski sporazum). Na sastanku Evropskog saveta krajem decembra iste godine, Srbija je dobila zeleno svetlo da formalno počne pregovore o pristupanju. ${ }^{70} \mathrm{Od}$ prve Međuvladine konferenciji EU i Srbije iz januara 2014. godine do decembra 2015. nije otvoreno nijedno od 35 poglavlja pristupnih pregovora. U tom periodu, Srbija je sa Kosovom ipak zaključila još četiri sporazuma - o zajednici srpski opština, energetici, telekomunikacijama i prohodnosti mitrovačkog mosta.

Kad je u pitanju odnos Srbije prema ZSBP, odnosno otvaranje poglavlja 31 (spoljna, bezbednosna i odbrambena politika), ni tzv. klauzula o ravnoteži ne pomaže. Savet Evropske unije izgleda ne namerava da usvoji izveštaj sa skrininga za ovo poglavlje. Glavna prepreka u vezi napretka poglavlja 31 ostaje neusklađivanje politike Srbije prema politici sankcionisanja koje EU koristi protiv Rusije zbog krize u Ukrajini. Usklađivanje spoljne politike Srbije sa EU je predviđeno od potpisivanja SSP, Srbije sa EU. Član 10, SSP je precizirao obaveze Republike Srbije kada je reč o ZSBP kroz „veće približavanje stavova strana o međunarodnim pitanjima, uključujući pitanja u vezi sa ZSBP, između ostalog i kroz odgovarajuću razmenu informacija, a posebno o pitanjima koja bi mogla da imaju značajan uticaj na strane" i „zajedničkih stavova o bezbednosti i stabilnosti u Evropi, uključujući saradnju u oblastima obuhvaćenim ZSBP EU”. 72 Obaveza usklađivanja sa EU u oblasti spoljne i bezbednosne politike je takođe deo dokumenta o pristupanju iz pr-

\footnotetext{
${ }^{68}$ Više o tome u: European Comission, Enlargement Strategy and Main Challenges 2012-2013, izvor:internet: https://ec.europa.eu/neighbourhood-

enlargement/sites/near/files/pdf/key_documents/2012/package/strategy_paper_2012_en.pdf (pristupljeno 08.07.2019)

${ }^{69}$ Više o tome u: European Comission, EU Enlargement strategy 2015. izvor: internet: https://ec.europa.eu/neighbourhood-enlargement/sites/near/files/20151110_strategy_paper_en.pdf (pristupljeno 08.07.2019.); European Comission, Communication on EU Enlargement Policy 2016, izvor: internet: https://ec.europa.eu/neighbourhood-enlargement/sites/near/files/20161109_strategy_paper_en.pdf (pristupljeno 08.07.2019.); European Comission, EU Enlargement Strategy 2016-2017, izvor: internet: http://edz.bib.uni-mannheim.de/edz/doku/adr/2017/cdr-2017-0093-en.pdf (pristupljeno 08.07.2019.); European Comission, A credible enlargement perspective for and enhanced EU engagement with the Western Balkans, izvor: internet:_https://ec.europa.eu/commission/sites/beta-political/files/communication-credible-enlargementperspective-western-balkans_en.pdf (pristupljeno 18.06.2019)

${ }^{70}$ Vlše o tome u: Slobodan Samardžić, Evropska unija: Sistem u krizi; sa studijom slučaja o odnosima Srbije i EU, Izdavačka knjižara Zorana Stojanovića, Sremski Karlovci-Novi Sad, 2016, str. 341-342.

71 Ibid.

${ }^{72}$ Više o tome u: Ministarstvo za evropske integracije, Republika Srbija, Sporazum o stabilizaciji i pridruživanju između evropskih zajednica i njihovih državnih članica sa jedne strane, i republike Srbije, sa druge strane, izvor: internet:http://www.mei.gov.rs/upload/documents/sporazumi_sa_eu/ssp_prevod_sa_anexima.pdf (pristupljeno 21.06.2019.), str. 11.; Marina Jovićević, Srbija i Zajednička spoljna i bezbednosna politika u: Miša Đurković, Milan Igrtinović (ur.), Zajednička spoljna i bezbednosna politika EU, Zuhra, Beograd, 2016, str. 25-26.
} 
ve Međuvladine konferenciji EU i Srbije iz januara 2014. godine. U članu 26 stoji da će do trenutka pristupanja od Srbije da se traži da postupno usklađuje svoje politike u odnosu na treće države, kao i svoje stavove u okviru međunarodnih organizacija sa politikama i stavovima koje usvoji Unija i njene države članice. ${ }^{73}$ Na osnovu objavljenih izveštaja Evropske komisije o napretku Srbije na putu ka EU, od 2014. godine (kada je počela kriza u Ukrajini), do 2018. godine može da se vidi da je Srbija imala prosečnu stopu pridruživanja ZSBP negde između 55-60 \% kad su u pitanju deklaracije EU i odluke Saveta ali nije se nijedne godine pridružila restriktivnim merama EU prema Rusiji. ${ }^{74}$

\section{Strategija Evropske komisije o proširenju iz 2018. godine kao još je- dan putokaz za Srbiju u neizvesnoj politici proširenja}

Kredibilna perspektiva proširenja ostaje određivajući pravac politike Evropske unije prema zemljama Zapadnog Balkana pa time i Srbiji. To može da se vidi i u poslednjoj Strategiji o proširenju Evropske komisije. Strategija o proširenju iz 2018. godine koja se zove „Kredibilna perspektiva proširenja za pojačan angažman EU prema Zapadnom Balkanom “75 dolazi kao neka vrsta putokaza ka pristupanju Evropskoj uniji koji je i dalje neizvestan. Kao što smo i ranije po-

${ }^{73}$ Council of the European Union, Conference of the accession to the European Union-Serbia-, Accession Document, Brussels, 9 January 2014, izvor:internet:

http://register.consilium.europa.eu/doc/srv?l=EN\&t=PDF\&gc=true\&sc=false\&f=AD\%201\%202014\%20INIT (pristupljeno 21.06.2019.), str. 12

${ }^{74}$ Izveštaj o napretku Srbije za 2018. godinu: Srbija se pridružila 34 od 65 deklaracija EU i odluka Saveta, što predstavlja stopu pridruživanja od blizu $52 \%$ u izveštajnom periodu. Srbija se, između ostalog, nije pridružila restriktivnim merama EU prema Rusiji; više o tome u: Evropska komisija, Izveštaj o napretku Srbije za 2018. godinu, izvor: internet:

http://www.mei.gov.rs/upload/documents/eu dokumenta/godisnji izvestaji ek o napretku/izvestaj ek o srbiji (1).pdf; (pristupljeno 19.06.2019) str 94.; Izveštaj o napretku Srbije za 2016. go dinu: Srbija se nije pridružila odlukama Saveta koje uključuju restriktivne mere EU koje se odnose na Rusiju ili pitanja koja se tiču interesa Rusije, kao ni odlukama Saveta o Kini, Bosni i Hercegovini, Moldaviji i Zimbabveu. Srbija se pridružila, kada je pozvana da to učini, 24 od 41 deklaracije EU i odluke Saveta, što predstavlja stopu pridruživanja od oko 59\%; više o tome u: Evropska komisija, Izveštaj o napretku Srbije za 2016. godinu, izvor: internet:

http://www.mei.gov.rs/upload/documents/eu_dokumenta/godisnji_izvestaji_ek_o_napretku/izvestaj_ek_srbija_2 016.pdf; (pristupljeno 19.06.2019) str 95.; Izveštaj o napretku Srbije za $201 \overline{5}$. godinu: Srbija se, kada je bila pozvana da to učini, pridružila 26 od 40 deklaracija EU i odluka Saveta (što predstavlja stopu pridruživanja od $65 \%$ u odnosu na $62 \%$ u prošlogodišnjem izveštaju). Srbija se nije pridružila odlukama Saveta, uključujući restriktivne mere EU u vezi sa nezakonitim otcepljenjem Krima od strane Rusije i događajima u istočnoj Ukrajini; više o tome u: Evropska komisija, Izveštaj o napretku Srbije za 2015. godinu; izvor: internet: http://www.mei.gov.rs/upload/documents/eu_dokumenta/godisnji_izvestaji_ek_o_napretku/godinji_izvestaj_15

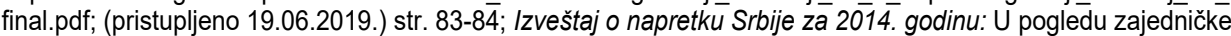
spoljne i bezbednosne politike (ZSBP), kada je pozvana da to učini, Srbija se pridružila 28 od 45 EU deklaracija i odluka Saveta (pridruživanje od $62 \%$ u odnosu na $89 \%$ tokom referentnog perioda iz Izveštaja o napretku za 2013. godinu)... Srbija se nije pridružila odlukama Saveta kojima se uvode restriktivne mere u kontekstu nezakonitog pripajanja Krima Rusiji i dešavanja u istočnom delu Ukrajine. više o tome u: Evropska komisija, Izveštaj o napretku Srbije za 2014. godinu; izvor: internet:

http://www.mei.gov.rs/upload/documents/eu_dokumenta/godisnji_izvestaji_ek_o_napretku/lzvestaj_o_napretku _dec14.pdf ; (pristupljeno 19.06.2019.) str. 108-109.

${ }^{75}$ European Comission, A credible enlargement perspective for and enhanced EU engagement with the Western Balkans, izvor: internet: https://ec.europa.eu/commission/sites/beta-political/files/communicationcredible-enlargement-perspective-western-balkans_en.pdf (pristupljeno 18.06.2019.) 
menuli, dokument počinje citiranjem izjave iz 2017. godine, predsednika Evropske komisije Junkera, koji je ponovo potvrdio evropsku budućnost zemalja Zapadnog Balkana ali i uz konstataciju da neće biti proširenja tokom mandata te komisije i parlamenta"176 Dalje kako smo takođe naveli vezanu za ovu strategiju, Evropska komisija je obećala da će tokom 2018. izložiti niz inicijativa usmerenih na poboljšanje demokratskog, institucionalnog i političkog okvira za uniju 2025. godine, dok se naglašava da do tog datuma, EU bi mogla postati veća od 27 članova. ${ }^{77}$ Kao potencijalni kandidati za pristupanje Uniji te godine se navode Srbija i Crna Gora s obzirom da je konstatovano da su pregovori o pristupanju na dobrom putu. ${ }^{78}$ Takođe je rečeno da je između 2007-2017. godine, EU uložila više od 8,9 milijardi evra kroz Instrument pretpristupne pomoći (IPA) dok je za 2018. godinu predviđeno 1,07 milijardi evra. ${ }^{79}$ Kad je u pitanju Srbija, ono što pada u oči u ovoj strategiji jeste potreba Evropske komisije da ponavlja rečenicu da je „sveobuhvatni, pravno obavezujući sporazum o normalizaciji hitan i od odlučnog značaja, kako bi Srbija i Kosovo mogle da napreduju na svojim evropskim putevima“" ${ }^{80}$

Crna Gora očigledno nema takvih prepreka, ali neće ulaziti u Uniju pre 2025. godine. Za ostale zemlje, ova strategija nije baš puno ponudila sem konstatacija da Albanija i Bivša Jugoslovenska Republika Makedonija ${ }^{81}$ ostvaruju značajan napredak na svom evropskom putu i da je Evropska komisija spremna da pripremi preporuke za otvaranje pregovora o pristupanju, na osnovu ispunjenih uslova. ${ }^{82}$

U pogledu obaveza prema Evropskoj uniji ali istovremeno i podrške Unije o njihovom ispunjavanju, ova strategija nije ponudila ništa novo sem niz reprezentativnih inicijativa ( range of flagship initiatives) među kojima spadaju već poznati „stari“ uslovi: jačanje vladavine prava, dalje angažovanje u bezbednosnim imigracionim pitanjima, socijalno-ekonomski razvoj, povećavanje povezanosti među zemlja (u infrastrukturnom i energetskom smislu), pomirenje i dobrosusedski odnosi. ${ }^{83}$

\section{Šta posle Strategije Evropske komisije o proširenju iz 2018. godine? Koliko je daleko 2025. godina?}

„Nadam se da se Evropa neće raspasti“, ${ }^{84}$ reče Ivan Krastev, u njegovoj knjizi „Posle Evrope“. Autor pretpostavlja da ako dođe do raspada Unije to će pre biti „nehotična posledica dugoročne disfunkcionalnosti. “" ${ }^{* 5}$ Kao mogućnost opstanka Evrope, Krastev pominje fleksibilnost (duh kompromisa, pregovore, prihvatanje ponešto od politike neprijatelja)

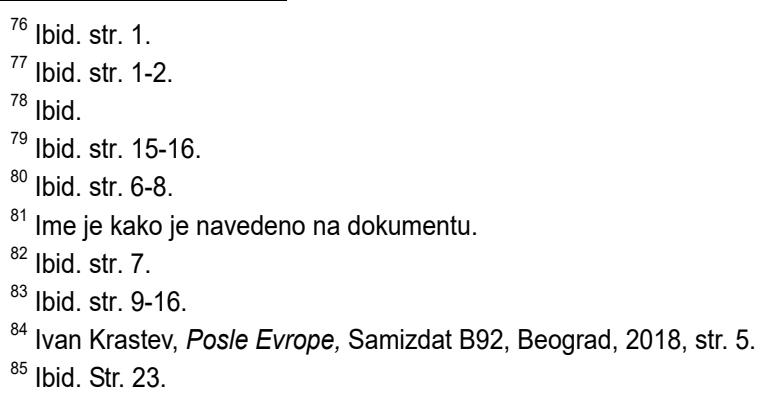


a ne rigidnost. Ipak autorov „optimistički trenutak nade“ o opstanku Evropske unije se ponovo završava skepticizmom. Na kraju, poruka knjige glasi da je preživljavanje kao pisanje pesme, čak ni pesnik ne zna kako će se završiti. ${ }^{86}$ Još jedno skeptično mišljenje ali u ovom slučaju vezano za perspektivu Zapadnog Balkana u EU, može da se nađe u knjizi "Glad i bes“ autora Jasmina Mujanovića koji nije siguran da li Brisel namerava da „apsorbira" region kao takav ili samo da menadžira njegovu post-konfliktnu situaciju. ${ }^{87}$

Zemlje Zapadnog Balkana zajedno sa Srbijom ipak se nadaju da se Evropska unija neće raspasti dok ciljaju ka pristupanju Uniji. Postoje čak raznovrsna mišljenja o tome kako olakšati pristup pridruživanju i eventualno ubrzavati članstvo u Evropskoj uniji. Primera radi, tri alternativna koncepta koji uključuju različite nivoe pridruživanja i integracije: udruživanje plus (association plus) - (EU proširuje nivo saradnje sa susednim zemljama, ali očigledno ostaje unutar paradigme asocijacije), delimično članstvo (partial membership) - (države postaju de facto članice EU u određenim oblastima) i ograničeno članstvo (limited membership) - (nova zemlja EU ne uživa sve prednosti članstva jer je isključena iz određenih oblasti politike) su već predložena 2008. godine uz napomenu da bi to moglo da dovede do eventualne kategorizacije „drugorazrednog članstva“ (second class membership). ${ }^{88}$ Kasnije, kao opcije ka brzom proširenju se pominju i predlozi o Balkanskom „velikom prasku“ ${ }^{89}$ ili preoblikovanje pristupa EU proširenju integracijom post-pristupnog mehanizma uslovljavanja koji bi osigurao da se vlade tih zemalja drže pod kontrolom na verodostojan način nakon što postanu članice EU. ${ }^{90}$ Malo skromniji predlog (jer ne predviđa neposredno članstvo) je i taj da se uvedu mape puta (RM/road maps) sa jasnim rokovima za identifikovanje ključnih prekretnica za dostizanje sledeće faze u procesu pridruživanja: dobijanje statusa kandidata; otvaranje pregovora; uspešno okončanje proces pregovora. ${ }^{91}$ Pesimistično rešenje koji se ipak bazira na načelu reciprociteta jeste predlog prema kome oslanjajući se na praksu diferencirane integracije, Srbija bi mogla da odgovori inicijativom za diferencirano pridruživanje. ${ }^{92}$ Interesantan je i predlog o „resetovanju“ politike EU prema zemljama Zapadnog Balkana u smislu redizajniranja mreže podržavajućih ili komplementarnih politika koje bi trebalo da podrže reforme vezane za pristupanje i punu demokratizaciju politika u regionu. ${ }^{93}$

Dok nijedan od gore navedenih predloga nije do sada prihvaćen, pristupni pregovori se odvijaju na osnovu politike kredibilnog proširenja. U Srbiji, domaći političari ne prestaju sa licitiranjem

\footnotetext{
${ }^{86}$ Ibid. str. 106.

${ }^{87}$ Jasmin Mujanović, Hunger and Fury: The Crisis of Democracy in the Balkans. Oxford University Press, New York, 2018. str. 105.

${ }^{88}$ više o tome u: Janis A. Emmanouilidis, Alternatives between Full Membership and Non-Membership - Fata Morgana or Silver Bullet?, Hellenic Foundation for European and Foreign Policy, Athens, 2008, str. 11-22.

${ }^{89}$ više o tome u: Centre for Southeast European Studies, Balkans in Europe Policy Advisory Group, THE UNFULFILLED PROMISE: COMPLETING THE BALKAN ENLARGEMENT, policy paper, 2014, str. 6-22.

${ }^{90}$ više o tome u: Milena Lazarević, Away with the enlargement bogeyman, izvor: internet: https://cep.org.rs/wp-content/uploads/2018/07/Away-with-the-Enlargement-Bogeyman_CEP.pdf; (pristupljeno 19.06.2019), str. 1-10.

${ }^{91}$ Vladimir Međak, Duško Lopandić, Maja Bobić, Ivan Knežević, Twelve proposals for EU enlargement from the Western Balkans, Grafolik, Belgrade, 2018, str. 11.

${ }^{92}$ Slobodan Samardžić, Evropska unija: Sistem u krizi; sa studijom slučaja o odnosima Srbije i EU, Izdavačka knjižara Zorana Stojanovića, Sremski Karlovci-Novi Sad, 2016, str. 347.

${ }^{93}$ Više o tome u: Toby Vogel, Beyond Enlargement, Why the EU's Western Balkans Policy Needs a Reset, izvor: internet: http://library.fes.de/pdf-files/bueros/sarajevo/14368.pdf (pristupljeno 19.06.2019), str. 19.
} 
godine pristupanja - od 2007 (Živković), preko 2012 (Dinkić), 2014 (Đelić), 2018 (Vučić) do 2025-27 (opet Vučić)... ${ }^{94}$ Dok Evropska komisija načelno podržava proširenje, pojedine zemlje članice imaju drugačiji stav. U tome prednjači Francuska, koja nije naklonjena proširenju. ${ }^{95}$

Kredibilna politika proširenja koja svakoj zemlji Zapadnog Balkana određuje uslove koje treba da ispunjava, bi mogla da bude fleksibilnija ukoliko Unija zaista misli da prihvati ove zemlje kao njene članove. Videli smo da krize sa kojima se suočavala Evropska unija od njenog osnivanja nisu je sprečile da se proširi. Nedovoljno izvršene reforme nisu sprečile ni Bugarsku pa ni Hrvatsku da se pridruže Evropskoj uniji. Političko uslovljavanje koje u slučaju Srbije implicitno znaci priznavanje nezavisnosti Kosova i suprotstavljanje Rusiji nije nikakva garancija da će Srbija postati član Evropske unije. Kako stvari stoje, ni Severna Makedonija koja je rešila spor oko imena sa Grčkom i time se otarasila „političkog uslovljavanja“ neće skoro u EU. U vezi Crne Gore nije jasno zašto ne može u EU pre 2025. godine (recimo po modelu Bugarske) iako ova zemlja nema takvih „glavobolja" poput njenih suseda, Srbije ili do skora Severne Makedonije.

Članstvo u EU treba i dalje da bude spoljnopolitički prioritet Srbije i njenih susednih zemalja ali Evropska unija treba da vodi jasnu politiku o proširenju. Zamor od proširenja koji već prouzrokuje zamor od čekanja se ne uklapa u sliku Zapadnog Balkana kao deo Evropske unije kako je bio zamišljen u Solunskoj deklaraciji iz 2003. godine. Da li će se Evropska unija jednog dana proširiti i prihvatiti odjednom (ili ponaosob) zemlje Zapadnog Balkana to ostaje da se vidi. Godina 2025. bi mogla da bude godina proširenja ukoliko Evropska unija to zaista želi.

\section{Bibliografija}

[1] BALKAN INSIGHT, Enlargement Stays off Agenda at Sofia Summit. http://www.balkaninsight.com/en/article/sofia-summit-balkans-meet-europe-for-the-first-time-in-15years-05-17-2018 (pristupljeno 26.06.2019)

[2] B92, 2018. French president: EU must first reform, Balkans can wait. https://www.b92.net/eng/news/world.php?yyyy=2018\&mm=04\&dd=17\&nav_id=103956 (pristupljeno 26.06.2019)

[3] B92, Mnogi misle da je jedini uslov za EU Kosovo. Nije., izvor: internet: https://www.b92.net/info/vesti/index.php?yyyy=2018\&mm=10\&dd=22\&nav_category=1262\&nav_id $=1458960 ;$ (pristupljeno 20.06.2019)

[4] Blic novine, HLADAN TUŠ BERLINA Bajer Bez priznanja Kosova Srbija NEĆE UĆI U EU, izvor: internet: https://www.blic.rs/vesti/politika/hladan-tus-berlina-bajer-bez-priznanja-kosova-srbijanece-uci-u-eu/hcj7ffg; (pristupljeno 20.06.2019)

[5] Centre for Southeast European Studies, Balkans in Europe Policy Advisory Group, THE UNFULFILLED PROMISE: COMPLETING THE BALKAN ENLARGEMENT, policy paper, 2014.

[6] Council of the European Union, Conference of the accession to the European UnionSerbia-, Accession Document, Brussels, 9 January 2014, izvor: internet: http://register.consilium.europa.eu/doc/srv?l=EN\&t=PDF\&gc=true\&sc=false\&f=AD\%201\%202014 \%20INIT (pristupljeno 21.06.2019)

\footnotetext{
${ }^{94}$ Više o tome u: Slobodan Samardžić, Da li je evropska unija naša sudbina u u Slobodan Samardžić, Ivana Radić Milosavljević (ur.), Evropska unija, nove i stare dimenzije krize, Čigoja štampa, Beograd, 2017, str. 110-111.

${ }^{95}$ Suzana Grubješić, Dometi Zapadnobalkanske Agende u: Dragan R. Simić, Dejan Milenković, Dragan Živojinović (ur.), Evropa za mene, Čigoja štampa, Beograd, 2018., str. 688-689.
} 
[7] Danas novine, Vučić: Najveći problem evrointegracija je Kosovo, ne vladavina prava, izvor: internet: https://www.danas.rs/politika/vucic-najveci-problem-evrointegracija-je-kosovo-ne-vladavina-prava/; (pristupljeno 20.09.2019)

[8] Delegation of the European Union to the Republic of Serbia, FDI to Serbia, izvor: internet: https://europa.rs/serbia-and-the-eu/trade/fdi-in-serbia/?lang=en ; (pristupljeno 20.06.2019.)

[9] Die Bundesregierung, Press release, Final Declaration by the Chair of the Conference on the Western Balkans, 28 August 2014, izvor: internet: https://archiv.bundesregierung.de/archivde/meta/startseite/final-declaration-by-the-chair-of-the-conference-on-the-western-balkans754634; (pristupljeno 20.06.2019)

[10] Dragan R. Simić, Dejan Milenković, Dragan Živojinović (ur.), Evropa za mene, Čigoja štampa, Beograd, 2018.

[11] Duško Lopandić, Evropska unija i Srbija - novo vreme i novo okruženje, Štampa Grafolik, Beograd, 2017.

[12] Eurobarometer 67, November 2007, Public opinion in the European Union, izvor: internet: http://ec.europa.eu/commfrontoffice/publicopinion/archives/eb/eb67/eb67_en.pdf ; str. 188-190.

[13] European Comission, A credible enlargement perspective for and enhanced EU engagement with the Western Balkans, izvor: internet: https://ec.europa.eu/commission/sites/betapolitical/files/communication-credible-enlargement-perspective-western-balkans_en.pdf (pristupljeno 18.06.2019)

[14] European Comission, Enlargement Strategy and Main Challenges 2010-2011. https://ec.europa.eu/neighbourhoodenlargement/sites/near/files/pdf/key_documents/2010/package/strategy_paper_2010_en.pdf (pristupljeno 27.06 2019)

[15] European Comission, Enlargement Strategy and Main Challenges 2012-2013, izvor: internet: https://ec.europa.eu/neighbourhoodenlargement/sites/near/files/pdf/key_documents/2012/package/strategy_paper_2012_en.pdf (pristupljeno 08.07.2019)

[16] European Comission, Enlargement Strategy and Main Challenges 2013-2014, izvor: internet: https://ec.europa.eu/neighbourhood-

enlargement/sites/near/files/pdf/key_documents/2013/package/strategy_paper_2013_en.pdf (pristupljeno 08.07.2019)

[17] European Comission, EU Enlargement strategy 2015. izvor:internet: https://ec.europa.eu/neighbourhood-enlargement/sites/near/files/20151110_strategy_paper_en.pdf (pristupljeno 08.07.2019.)

[18] European Comission, Communication on EU Enlargement Policy 2016, izvor: internet: https://ec.europa.eu/neighbourhood-enlargement/sites/near/files/20161109_strategy_paper_en.pdf (pristupljeno 08.07.2019.)

[19] European Comission, EU Enlargement Strategy 2016-2017, izvor: internet: http://edz.bib.uni-mannheim.de/edz/doku/adr/2017/cdr-2017-0093-en.pdf (pristupljeno 08.07.2019)

[20] European Committee of the Regions, EU Enlargement Strategy 2016-2017, izvor: internet: http://edz.bib.uni-mannheim.de/edz/doku/adr/2017/cdr-2017-0093-en.pdf (pristupljeno 19.06.2019)

[21] European Comission, European Union Trade in goods with Western Balkans 6 2007-2017, izvor: internet: https://webgate.ec.europa.eu/isdb_results/factsheets/region/details_western-balkans6_en.pdf (pristupljeno 19.06.2019), str.8.

[22] European Commission, 10229/03 (Presse 163), EU-Western Balkans Summit, Thessaloniki, 21 June 2003, izvor: internet: http://europa.eu/rapid/press-release_PRES-03-163_en.htm; (pristupljeno 17.06.2019) 
[23] European Comission, Standard Eurobarometer, No. 79, Spring 2013, izvor: internet: http://ec.europa.eu/commfrontoffice/publicopinion/archives/eb/eb79/eb79_anx_en.pdf, str. T84, (pristupljeno 18.06.2019)

[24] European Comission, 2003 Continuing enlargement - Strategy paper and Report of the European Commission on the progress towards accession by Bulgaria, Romania and Turkey. https://www.esiweb.org/enlargement/wp-content/uploads/2009/02/ec-2003-strategy-paper.pdf (pristupljeno 26.06.2019)

[25] European Commission, Serbia 2019 Report, Brussels, 29.5.2019 SWD (2019) 219 final, izvor: internet: https://ec.europa.eu/neighbourhood-enlargement/sites/near/files/20190529-serbia-report.pdf; (pristupljeno 27.06.2019) str.3.

[26] European Council, A Secure Europe in a better world-European Security Strategy, Brussels, 12 December 2003, izvor: internet: http://eclan.eu/files/attachments/.1615/doc_10184_290_en.pdf; (pristupljeno 08.07.2019)

[27] European Parliament, Copenhagen European Council - 21-22 June 1993, izvor: internet: http://www.europarl.europa.eu/enlargement/ec/cop_en.htm ; (pristupljeno 18.06.2019)

[28] European Union External Action, Shared Vision, Common Action: A Stronger Europe; A Global Strategy for the European Union's Foreign and Security Policy, June 2016, izvor: internet: http://eeas.europa.eu/archives/docs/top_stories/pdf/eugs_review_web.pdf (pristupljeno 19.06.2019)

[29] EU business, Juncker to halt enlargement as EU Commission head, Izvor: internet: https://www.eubusiness.com/news-eu/politics-juncker.x29 ; (pristupljeno 19.06.2019)

[30] EU-Western Balkans Summit, Sofijska deklaracija, 17. maj 2018. godine, izvor: internet: https://www.consilium.europa.eu/media/34805/sofia-declaration_bs.pdf (pristupljeno 19.06.2019)

[31] Evropska komisija, Izveštaj o napretku Srbije za 2014. godinu; izvor: internet: http://www.mei.gov.rs/upload/documents/eu_dokumenta/godisnji_izvestaji_ek_o_napretku/lzvestaj _o_napretku_dec14.pdf ; (pristupljeno 19.06.2019.) str.108-109.

[32] Evropska komisija, Izveštaj o napretku Srbije za 2015. godinu; izvor: internet: http://www.mei.gov.rs/upload/documents/eu_dokumenta/godisnji_izvestaji_ek_o_napretku/godinji_ izvestaj_15_final.pdf ; (pristupljeno 19.06.2019)

[33] Evropska komisija, Izveštaj o napretku Srbije za 2016. godinu, izvor: internet: http://www.mei.gov.rs/upload/documents/eu_dokumenta/godisnji_izvestaji_ek_o_napretku/izvestaj _ek_srbija_2016.pdf ; (pristupljeno 19.06.2019)

[34] Evropska komisija, Izveštaj o napretku Srbije za 2018. godinu, izvor: internet: http://www.mei.gov.rs/upload/documents/eu_dokumenta/godisnji_izvestaji_ek_o_napretku/izvestaj _ek_o_srbiji(1).pdf ; (pristupljeno 19.06.2019)

[35] Evropska komisija, Saopštenje o politici proširenja za 2016. godinu, izvor: internet: http://www.mei.gov.rs/upload/documents/eu_dokumenta/godisnji_izvestaji_ek_o_napretku/saopste nje_ek_o_politici_prosirenja_16.pdf ; (pristupljeno 19.06.2019)

[36] INTERMAGAZIN.RS, NEMAČKA OBJAVILA plan za Balkan - „BERLIN PLUS“, izvor: internet: https://www.intermagazin.rs/nemacka-objavila-plan-za-balkan-berlin-plus/; (pristupljeno 27.06.2019)

[37] Ivan Krastev, Posle Evrope, Samizdat B92, Beograd, 2018.

[38] Janis A. Emmanouilidis, Alternatives between Full Membership and Non-MembershipFata Morgana or Silver Bullet?, Hellenic Foundation for European and Foreign Policy, Athens, 2008.

[39] Jasmin Mujanović, Hunger and Fury: The Crisis of Democracy in the Balkans. Oxford University Press, New York, 2018.

[40] Jovan Teokarević, Western Balkan's EU integration: How to overcome the remaining obstacles, ivor: internet: https://drive.google.com/drive/mobile/folders/OB3p2GDMDp_RbF96NFpUZ2NuRIU?usp=sharing_eip\&invite=CKTK2-gL\&ts=5c0a2601; (pristupljeno 17.06.2019) 
[41] Loukas Tsoukalis, The unhappy state of the union; Europe needs a new grand bargain, Policy Network, London, 2014.

[42] Milena Lazarević, Away with the enlargement bogeyman, izvor: internet: https://cep.org.rs/wp-content/uploads/2018/07/Away-with-the-Enlargement-Bogeyman_CEP.pdf; (pristupljeno 19.06.2019)

[43] Ministarstvo spoljnih poslova Republike Srbije, Berlinski proces, izvor: internet: http://www.mfa.gov.rs/sr/index.php/spoljna-politika/eu/regionalna-saradnja/2016-11-04-09-0426?lang=lat ; (pristupljeno 21.06.2019)

[44] Ministarstvo za evropske integracije, Republika Srbija, Sporazum o stabilizaciji i pridruživanju između evropskih zajednica i njihovih državnih članica sa jedne strane, i republike Srbije, sa druge strane, izvor:

internet:http://www.mei.gov.rs/upload/documents/sporazumi_sa_eu/ssp_prevod_sa_anexima.pdf (pristupljeno 21.06.2019)

[45] N1, Dačić: Zbog plana Berlin plus da ne ostanemo u čekaonici EU, izvor: internet: http://rs.n1info.com/Vesti/a274280/Dacic-o-planu-Berlin-plus.html (pristupljeno 27.06.2019)

[46] Official Journal of the European Union, CONSOLIDATED VERSION OF THE TREATY ON THE FUNCTIONING OF THE EUROPEAN UNION, 26.10.2012. izvor: internet: https://eur-lex.europa.eu/legal-content/EN/TXT/PDF/?uri=OJ:C:2012:326:FULL\&from=EN; (pristupljeno 17.06.2019.)

[47] Republika Srbija, Ministarstvo za evropske integracije, Evropska orijentacija građana Srbije, Ispitivanje javnog mnjenja, decembar 2018. godine, izvor: internet: http://www.mei.gov.rs/upload/documents/nacionalna_dokumenta/istrazivanja_javnog_mnjenja/javn o_menjnje_decembar_18.pdf (pristupljeno 18.06.2019)

[48] Republika Srbija, Ministarstvo za evropske integracije, Instrument za pretpristupnu pomoć 2014-2020, izvor:internet: http://www.mei.gov.rs/srl/fondovi/fondovi-evropske-unije/ipa-instrumentza-pretpristupnu-pomoc/instrument-za-pretpristupnu-pomoc-2014-2020/; (pristupljeno 25.06.2019)

[49] RTS, Aleksandar Vucic: "Članstvo u EU spoljnopolitički prioritet Srbije", http://www.rts.rs/page/stories/sr/story/9/politika/3304233/clanstvo-u-eu-spoljnopoliticki-prioritetsrbije.html ; (pristupljeno 25.06.2019)

[50] Saša Dimitrijević, novine Politika, Politika Stamparija d.o.o, Beograd, 28.10.2018, str.1.

[51] Slobodan Samardžić, Evropska unija: Sistem u krizi; sa studijom slučaja o odnosima Srbije i EU, Izdavačka knjižara Zorana Stojanovića, Sremski Karlovci-Novi Sad, 2016. krize, Čigoja štampa, Beograd, 2017.

[52] Toby Vogel, Beyond Enlargement, Why the EU's Western Balkans Policy Needs a Reset, izvor: internet: http://library.fes.de/pdf-files/bueros/sarajevo/14368.pdf (pristupljeno 19.06.2019)

[53] Vladimir Međak, Duško Lopandić, Maja Bobić, Ivan Knežević, Twelve proposals for EU enlargement from the Western Balkans, Grafolik, Belgrade, 2018.

[54] Zoran Nechev, Ivan Nikolovski, Jelica Minić, Mariola Qesaraku and Adnan Ćerimagić 2018 Western Balkans Summit: 3 key takeaways from London; izvor: internet: https://idscs.org.mk/wpcontent/uploads/2018/12/Финална-верзија-на-брифр-веб-2.pdf ; (pristupljeno 18.06.2019)

[55] Western Balkans Summit, London 2018, Joint Declaration on Regional Cooperation and Good Neighbourly Relations in the Frame of the Berlin Process, izvor: internet: https://assets.publishing.service.gov.uk/government/uploads/system/uploads/attachment_data/file/ 724294/180710_WBS_Joint_Declarations.pdf ( pristupljeno 18.06.2019) 